\title{
STUDENTS AND THE MILITARY: REGIME FRICTION AND CIVILIAN DISSENT IN THE LATE SUHARTO PERIODı
}

\author{
E. Aspinall
}

Much of the recent literature on democratic transitions from authoritarian rule has stressed the importance of regime disunity in the early stages of the transition. For example, Guillermo O'Donnell and Philippe Schmitter have written: ${ }^{2}$

... there is no transition whose beginning is not the consequence-direct or indirect-of important divisions within the authoritarian regime itself, principally along the fluctuating cleavage between hard-liners and soft-liners.

Similarly, Adam Przeworski argues: ${ }^{3}$

Where some perspectives of an "opening" (apertura, "thaw") have appeared, they have always involved some ruling groups that sought political support amongst forces until that moment excluded from politics by the authoritarian regime. This is not to say that once liberalisation is initiated, only such chosen partners are politically mobilised: once the signal is given, a wave of popular mobilisation often ensues. But it seems to me that the first critical threshold in the transition to democracy is precisely the move by some group within the ruling bloc to obtain support from sources external to it.

\footnotetext{
${ }^{1}$ This article is based on a paper presented to the Asian Studies Association of Australia Biennial Conference in Perth, July 13-16, 1994, and was written mainly in May 1994. Information in it is largely drawn from fieldwork carried out between March 1993 and March 1994 in Jakarta and other towns in Java. All unattributed quotations are from interviews carried out with student activists during this time. For obvious reasons, informants are not identified and many details in descriptions of events which would assist their identification or that of the groups that they belong to have been omitted. My thanks to the Indonesian student activists who discussed their experiences with me, and to Harold Crouch and Ben Kerkvliet for their comments.

2 Guillermo O'Donnell and Philippe C Schmitter, Transitions from Authoritarian Rule: Tentative Conclusions about Uncertain Democracies (Baltimore: John Hopkins University Press, 1986), p. 19.

${ }^{3}$ Adam Przeworski, "Some Problems in the Study of the Transition to Democracy," in Transitions from Authoritarian Rule: Comparative Perspectives, ed. O'Donnell et al., p. 56.
} 
In recent years Indonesian politics have seemingly been marked by some of these characteristics.

On the one hand, there has been partly hidden, but sometimes bitter, friction between elements in the military and the president (along with the "palace group" more broadly). A process of limited liberalization has taken place. This in turn has been accompanied by an increase in public criticism and dissent, most obvious in the reemergence of public protest and (at least until mid-1994) a relatively vocal press. This article examines the relationship between intra-regime disunity and civilian dissent by focusing on one section of the civilian opposition: student activist groups. It examines their relationship with military elements, and the strategic debates amongst them which have been prompted by perceived conflict "at the top." The focus is on the period from late 1988 to early 1994.

\section{Friction in the Military}

Dissatisfaction within the officer corps of ABRI (the Indonesian Armed Forces) in recent years has been linked with a range of disparate issues, including sudden or "unfair" promotions and transfers, "scapegoating" of the military for human rights violations, and interference by non-military politicians in purchases of armaments and equipment. This has often been combined with resentment at the increasing wealth and assertiveness of the Suharto family and their associates, and has all occurred in the atmosphere of tension associated with anticipation of the long awaited presidential succession. Underlying such grumbles have been three main factors: first, various long-term processes of political and economic change; second, generational change in the military; and, third, the role of the Benny Moerdani network.

In the first place, there has been a long-term, albeit gradual, decline in the role played by the military in the New Order regime. ${ }^{4}$ Whereas in the early 1970 s the military more or less constituted government, since the 1980 s a growing gap has become apparent, symbolized graphically by the minimal military representation in the Sixth Development Cabinet announced in March 1993. Although the military as an institution remains very powerful, government is increasingly legitimated by civilian mechanisms, more civilians have been moving into its top levels, and the institutional interests of the military less and less occupy a central part in policy formulation:

ABRI has become increasingly an instrument carrying out general policies which it has no real say in formulating. The Suharto regime is not a military regime but a militarist regime-it uses military force to rule but the interests of the military as a social or political group are not its first concern. ${ }^{5}$

The growing political marginalization of the military at the upper echelons of government reflects the expanding power of the "notables" centered on the Suharto family and the families of other senior bureaucrats. ${ }^{6}$ Over the New Order period, using their access to strategic positions in the state, these groups have engaged in massive capital accumulation.

\footnotetext{
${ }^{4}$ For discussions of this process, see for example: Harold Crouch "Democratic Prospects in Indonesia," in Democracy in Indonesia: 1950s and 1990s, ed. David Bourchier and John Legge (Clayton: Monash University Centre of Southeast Asian Studies, 1994), pp. 120-23; Max Lane, 'Openness,' Political Discontent and Succession in Indonesia: Political Developments in Indonesia, 1989-1991 (Brisbane: Griffith University, Australia-Asia Paper No. 56, 1991), Pp. 4-16.

${ }^{5}$ Lane, 'Openness,' Political Discontent and Succession in Indonesia, p. 7.

6 The term "notables" is introduced by Richard Robison in "Organising the Transition: Indonesian Politics in 1993/94" in Indonesia Assessment 1994 (Canberra: Australian National University, 1994), p. 52.
} 
Under the economic deregulation which began in the mid-1980s they have been handed control over increasingly large parts of the economy. This process has speeded the displacement of the military from the commanding heights of the economy, with military-controlled foundations and state enterprises playing an ever more minor role. Richard Robison, for instance, notes that in the late 1980 s "... the military's lucrative forestry and transport monopolies had largely evaporated as better capitalised conglomerates and new family enterprises moved in." 7 The notables have also begun to play a more active political role, as evidenced by the inclusion of two of Suharto's children in the new Golkar Central Executive Board chosen at the 1993 congress. ${ }^{8}$ These developments-the increasing prominence of the Suharto family and other notables, as well as the military's apparently sliding political and economic position-have caused considerable concern and resentment within at least parts of the officer corps.

The generational change which took place in the military during the 1980 s has also exacerbated tensions between the President and elements in the officer corps. In the early New Order period, the military was led by Suharto's contemporaries from the 1945 generation. Officers like Ali Moertopo, Soedjono Hoemardani, Widodo, Panggabean, Mohammad Yusuf, and Yoga Sugama had been Suharto's comrades-in-arms through the struggle for independence, and the periods of parliamentary and guided democracy. They had participated with him (and in some cases directly under his command) in the overthrow of Sukarno and the establishment of the New Order. Although Suharto was unquestionably the supreme power in the New Order (and pushed aside 1945 generation officers when necessary), at least he considered them his peers, consulted with them, and valued their opinions. During the 1980s, the older generation was succeeded by officers trained at the Military Academy (AMN) in Magelang in the 1960s. There is a much greater gap between the president and these officers. Not only are they a full generation younger than he but they have had very different experiences, having seen active service almost entirely under the New Order. It is safe to assume that he trusts them less, and values their skills less. This accounts for the prominence of former presidential adjutants, relatives, and their protégés in recent promotions, especially to the most powerful and sensitive positions. ${ }^{9}$

The final factor which has had a decisive impact on the character of tensions has been the role of Benny Moerdani and his network. The Indonesian Armed Forces has always been permeated by informal networks, but that built around Moerdani was particularly powerful and pervasive. During the 1970 s, Moerdani attained a position of extraordinary power by his dominance of the military intelligence network, the linchpin of New Order control. He was at the height of his authority in the 1983-1988 period when he concurrently held the positions of commander in chief of the armed forces and minister of defense and security, while continuing to maintain his tight hold on the intelligence apparatus. Moerdani intervened extensively in promotions and transfers both within the military and outside of it (in the regional bureaucracy for example). He succeeded in building a powerful network of loyal officers throughout the military hierarchy and especially in the intelligence services. Moerdani had enjoyed a close personal relationship with Suharto dating back to the early 1960s (to which he owed his position). But by the late 1980s, the extent of his pow-

\footnotetext{
7 Richard Robison, "Indonesia: Tensions in State and Regime," in Southeast Asia in the 1990s: Authoritarianism, Democracy and Capitalism, ed. Richard Robison, Kevin Hewison, and Gary Rodan (Sydney: Allen and Unwin, 1993) p. 50.

${ }^{8}$ Robison, "Organising the Transition," pp. 56-57.

9 See the "Current Data on the Indonesian Military Elite" series in Indonesia on the implications of generational change, in particular, Indonesia 36 (October 1983) and 56 (October 1993).
} 
er (increasingly being used against his chief rival and fellow presidential favorite Sudharmono) seemed increasingly to represent a threat to the president himself. On February 27, 1988 , one month before the March MPR session, Moerdani was suddenly dismissed from his post as commander in chief. From then until 1993 he continued to wield considerable influence both as defense and security minister and through informal channels. However, it appears that over the past two years his personal influence and that of his network have been considerably reduced by promotions, transfers, and military restructuring. ${ }^{10}$

Tensions within the military have been most evident since early 1988, when Moerdani was dismissed as commander in chief and, one month later, Sudharmono was awarded the vice-presidency by the People's Consultative Assembly (MPR). Sudharmono was a Suharto protégé and, as state secretary and general chairperson of Golkar, had in some measure attempted to consolidate the independence and power of the bureaucracy (including Golkar's independence from, and even willingness to criticize, ABRI). He had also undercut the military's financial power and independence by his authority to decide on major government contracts. Leading up to the MPR session military elements, purportedly from the Moerdani camp, launched a gossip campaign concerning his alleged "Communist" past and supported an unprecedented vice-presidential challenge by Naro, chairperson of the PPP (Development Unity Party). In the MPR session itself, a previously little-known officer, Brigadier General Ibrahim Saleh, interrupted the election, storming to the podium and stating his disagreement with Sudharmono's candidacy. When this challenge was defeated, the military pushed to capture up to 70 percent of the regional representation to the $1988 \mathrm{Golkar}$ congress where Sudharmono was replaced as general chairperson by General Wahono, who was widely viewed as more sympathetic to military interests.

In more recent years the focus of most open military discontent has been Research and Technology Minister B.J. Habibie, who has emerged as Suharto's new right-hand man and the most prominent civilian in government. Military unhappiness has been prompted not only by the transfer to his jurisdiction of previously ABRI-owned enterprises and his role in costly armaments and equipment purchases, but also by the increasingly large role he plays in economic policy making and the awarding of government contracts, by his apparent ambition for the presidency, and by the part he has played for Suharto in seeking an institutional support base in the Muslim community through the Muslim Intellectuals' Organization, ICMI.11

The period since 1992 has been marked by two phenomena. In the first place, military officers have attempted to secure strategic positions which would put the military in a commanding position to determine the shape of a post-Suharto order. The clearest example of this was the 1993 elevation of Armed Forces Commander Try Sutrisno to the vice-presi-

\footnotetext{
10 In certain respects the intra-regime tensions of the late 1980 s and early 1990 s thus represent a continuation of a long-standing pattern of competition between factions centered on rival military officers, with the Soemitro versus Ali Moertopo rivalry of the early 1970 s as the classic case. Much of the apparent "military discontent" of recent years can in fact be attributed to rearguard actions mounted by Moerdani and many of his supporters. However, unlike during the frictions of the 1970s, dissatisfaction within the active officer corps has been substantially directed at the president and the palace group, rather than rival officers. And it has been apparent that many senior officers have felt that the institutional interests of the military have been threatened, due to the political and economic changes touched on above. Moerdani's entourage has, of course, attempted to play upon these concerns and act as army spokesperson with regard to them, but discontent has clearly not been limited to this group alone.

11 On Habibie, see for example, William Liddle, "Politics 1992-1993: Sixth Term Adjustments in the Ruling Formula," in Indonesia Assessment 1993, ed. Manning and Hardjono (Canberra: Australian National University, 1993), pp. 3-34; Harold Crouch, "Indonesia an Uncertain Outlook," Southeast Asian Affairs, 1994, p. 125.
} 
dency, a key position in the succession equation. This occurred by virtual fait accompli, with an unprecedented public announcement two weeks prior to the MPR that Try was the military's choice for the post. This manoeuver was engineered by Moerdani-associate Lieutenant General Harsudiyono Hartas, head of the Armed Forces faction in parliament at the time. Later in the year, as in 1988, military officers successfully secured the bulk of local and regional Golkar branches in preparation for the national congress-although in the end no confrontation took place and Suharto's nominee, Harmoko, was elected as the new general chairperson. ${ }^{12}$

Second, since 1992 a range of measures have been taken which were designed to reassert Suharto's control over the Armed Forces. These have included the removal of Moerdani from the cabinet, the rapid removal of Edi Sudradjat as commander in chief (after he made clear that he favored a military general chair for Golkar), numerous promotions and transfers in regional commands, and the reorganization of military intelligence (both widely interpreted as blows against the Moerdani network). As expected, Tien Suharto's brother-inlaw, Wismoyo Arismunandar has continued his rapid progress through the ranks and now occupies the position of army chief of staff. At the same time ABRI commander Feisal Tanjung has begun to effect an apparent reconciliation with Habibie, suggested by the replacement of Hariyoto by Hartono as the chief of staff for social and political affairs.

The apparent ease with which the above changes have been carried out clearly indicates that the divisions in the military should not be exaggerated. Political alignments in the Armed Forces have been both fluid and difficult to measure accurately. Anti-Suharto sentiment is clearly far from uniform, and may not even be dominant. Not only is the military permeated by Suharto loyalists, but ABRI's deeply ingrained doctrine of loyalty and discipline and a reluctance to provoke social unrest militate against action by those who are dissatisfied. Most officers remain sitting on the fence and even those (including from the Moerdani group) who have been most opposed to Sudharmono, Habibie, and the palace have been very hesitant and cautious. This is further compounded by Suharto's advanced age and the inevitability of his not-too-distant departure from the presidency. Discontented elements in the military have thus far avoided open confrontation, perhaps hoping to postpone it until the post-Suharto period, while in the meantime attempting to strengthen their position (though not necessarily always succeeding in doing so).

\section{Military Discontent and Liberalization}

From the late 1980s until mid-1994, largely coinciding with growing restlessness in the military, Indonesia experienced a (limited and uneven) loosening of political controls. There was increasingly open public debate on a range of policy matters, the press became remarkably critical, public protest became an everyday occurrence, and many critical and dissenting groups attained previously unthinkable public exposure. This was a complex process, and a wide range of factors contributed to it, including the social changes brought about by economic development, the changing international context, and imperatives for a more regularized framework for continued capitalist accumulation. This article does not seek to enter the broad debate about what have been the determining factors underlying keterbukaan. Rather it looks at the interface between military discontent and the activities of

\footnotetext{
12 Similarly, military elements (although here evidence is far from complete) played a role in the eventual confirmation of Megawati Soekarnoputri as leader of the PDI in late 1993. In particular, it appears that the military (except for officers most loyal to Suharto) largely abstained from the campaign of sabotage directed against her nomination which was instead attempted by the social and political affairs section of the Ministry of Internal Affairs, controlled by Suharto loyalist, Yogie SM (which spectacularly failed).
} 
dissenting groups (students). For present purposes, then, it is important to note that a number of observers have argued that military discontent is a, or indeed, the key cause of openness. For instance, Harold Crouch, ${ }^{13}$ referring to the situation leading up to the 1993 MPR session, argues:

The division between the government on one hand and the military leadership on the other has been the crucial condition for the keterbukaan (openness) of the past few years. . .. The military, as guardians of security, have adopted a liberal stance not because they are committed to democratic ideals but in order to put pressure on the government.

Similarly, in a number of recent articles and papers, Arief Budiman has argued that openness and the rise of an "under current" (arus bawah) of popular involvement in politics has been dependent on conflict at the regime level. ${ }^{14}$ It is also a significant theme in the 1993 book by Far Eastern Economic Review journalist Michael Vatikiotis. ${ }^{15}$

If we assume that fractures in the regime associated with discontent in some important military circles are indeed a key cause of liberalization, an obvious question arises: just how has this come about? Through what mechanisms has regime-level friction given rise to loosening up? In particular, what has been the relationship between military discontent and the increase in activity by dissenting and oppositional groupings in recent years?

Many possible mechanisms suggest themselves; here it is necessary to touch on just a few. First, there is a relatively straightforward role of "leading by example." The ABRI fraction in the 1988-1992 Parliament (DPR) played an important role in the initiation and promotion of the keterbukaan process. In 1989, via the Political and Social Affairs Commission, it held a series of sessions on openness. This initiative was enthusiastically taken up by the media, and made an important contribution to the legitimation of questioning and criticism. ${ }^{16}$ Again, Moerdani associate Harsudiyono Hartas was a key player in this process.

Second, it is often argued that the military has played a more indirect role, by loosening political controls and giving rein to civilian forces. Examples frequently cited include the military's apparently more lenient approach to protest, or its partial abstention from the campaign against Megawati's election to the leadership of the Indonesian Democracy Party (PDI).

Third, more than this, it is sometimes implied that military elements actively "encourage" challenges to the state, or that they have provided "backing" to critical groups, although it is often not made clear exactly what such "encouragement" consists of. For example, Vatikiotis, discussing military unhappiness with Sudharmono and the succession issue, writes: 17

13 Crouch, "Democratic Prospects in Indonesia," p. 121.

14 Arief Budiman: "Indonesian Politics in the 1990s," in Indonesia Assessment 1992: Political Perspectives on the 1990s, ed. Harold Crouch and Hal Hill (Canberra: Australian National University, 1992), pp. 130-39.; "From Lower to Middle Class: Political Activities before and after 1988," in Democracy in Indonesia, ed. Bourchier and Legge, pp. 229-35.; "People Power: Proses Yang Sedang Berjalan," Editor, January 7, 1994, pp. 28-29. A similar argument is made by Ichlasul Amal in an interview headlined Gerakan Mahasiswa Manifestasi Persaingan Antarelite Politik (The student movement is a manifestation of competition within the political elite) in Suara Merdeka, December 7, 1991.

${ }^{15}$ Indonesian Politics Under Suharto (London: Routledge, 1993).

${ }^{16}$ Lane, 'Openness,' Political Discontent and Succession in Indonesia, pp. 15-16.

17 Vatikiotis, Indonesian Politics Under Suharto, p. 162. At p. 5. Vatikiotis also writes of student protests which are "seemingly guided by the armed forces." 
Having failed to convince him of their wishes, Abri turned to the manipulation of social forces: a succession of strategies which drew on Abri's experience countering Communism in the mid-1960s. Students were persuaded to demonstrate, political levers were pulled within Golkar, and threats to stability were concocted.

An emphasis on this kind of clandestine encouragement reflects the state and elitecentered emphasis of the "cultural politics" and "patrimonial state" approaches to analyzing Indonesian politics, which have dominated much work by outside political scientists observing Indonesia since the late 1960s. These approaches lend themselves to tracing the causes of political conflict to the state elite, and especially (via patron-client pyramids) to factional disputes within that elite. ${ }^{18}$ In popular terms, this is often translated as the search for a political dalang (the puppeteer in Javanese wayang) responsible for the manipulation and "playing off" of less powerful groups. ${ }^{19}$

Fourth, one of the central themes of this article is that the mere existence of intra-regime friction, or at least a perception that such friction exists, encourages a "snowballing" of the mobilization and organization of dissenting and critical forces. Civilian groupings make a reading of politics at the regime level, analyze opportunities and spaces afforded them by such conflict, and attempt to make use of them. Thus, friction has promoted a vigorous and multi-faceted strategic debate among civilian groups which have long been excluded from power.

Finally, a perception on the part of the "Suharto camp" that there is significant military dissatisfaction has also played a role. According to a number of informants from elite Jakarta political circles, in recent years the president and senior officials around him have become increasingly convinced that a layer of dissatisfied army officers has been consolidating into an cohesive group, and that this group has been actively searching for allies and successfully building conspiratorial links with civilian politicians and activists. Such suspicions have been partially responsible for the palace group's own search for a new political constituency-especially amongst Islamic groups via ICMI. Along the way, further concessions have been made. The investigations into the massacres in Dili (East Timor) and Nipah (Madura), as well as the establishment of the National Human Rights Commission, were initiatives of the palace, and it has been the military which has borne the immediate brunt of them (in the case of the inquiry into the Dili massacre, a chief casualty was Moerdani man Panjaitan) ${ }^{20}$ It should thus be noted that disgruntled military elements have by no means been the only source within the regime of concessions (albeit token ones) in the direction of liberalization.

Much of the remainder of this article looks at the second, third, and fourth processes mentioned above in terms of relations between military elements and student activists.

\footnotetext{
${ }^{18}$ See for example, Karl Jackson, "Bureaucratic Polity: A Theoretical Framework for the Analysis of Power and Communications in Indonesia," in Political Power and Communications in Indonesia, ed. K. Jackson and L. Pye (Berkeley: University of California Press, 1978) p. 4.: "Whenever mass mobilization has occurred in Indonesia the initiative has always come from within the elite." Similarly, in a paper written early in the New Order period, Ann R. Willner argued that public protests in Indonesia "... tend to be provoked and planned from the top or close to it by one or several members of the political elite" who make use of their patron-client pyramids to mobilize their followers: Public Protest in Indonesia, (Athens, Ohio: Ohio University Center for International Studies, 1968), pp. 7-8.

19 The search for the dalang is, of course, also a part of the standard response of the regime to social or political unrest-most famously after Malari, where senior former politicians from the PSI (Indonesian Socialist Party) and Masjumi were scapegoated.

20 "Current Data on the Indonesian Military Elite," Indonesia 53 (April 1992): 100-101.
} 
Before proceeding, it is worth touching on two of the possible explanations which might account for the apparent promotion or tolerance of keterbukaan by military elements (to the extent that such tolerance has been conscious or intended).

First, it cannot be excluded that support for a new approach from sections of the military partly reflects the existence of a younger, more reformist and professional layer of officers within ABRI who recognize that changes in Indonesia's social structure and the global situation mean that the military's social and political role cannot remain unchanged, and hence contemplate some reduction or reformulation of the military role and some level of democratization. The vigorous proponents of keterbukaan in the ABRI/DPR fraction during the 1987-1992 period were younger middle-ranking officers, who were in fact reprimanded by Try Sutrisno at that time. Brigadier Roekmini Koesoemo Astoeti, for example, since her removal from the DPR has continued to be an active proponent of reform, openness, and democratization on the Jakarta seminar circuit, and, more recently, as a member of the National Human Rights Commission.

However, there is no evidence to point to the emergence of a vigorous military reform current committed to some kind of civilianized, more democratic, and liberal system. For every tentative step in favor of loosening up, there have been many pronouncements in the old vein, and $A B R I$ has continued to emphasize the centrality of security and stability, as attested to by the number of massacres of protesting civilians in recent years. According to several civilian sources interviewed in Jakarta in 1993-1994, indications are that those in ABRI who contemplate change envisage at most a somewhat cleaner and more efficient authoritarian government, with less flagrant corruption, and possibly with a greater watchdog role for the legislature. There have been no unequivocal indications from serving officers of support for more thorough reform. What we have witnessed, then, has not been a split between regime "soft-liners" in the military and "hard-liners" in the Suharto campinstead both sides are fundamentally authoritarian (although both may contain minority reformist elements).

The second explanation for military "encouragement," or toleration, of a thaw, is that it reflects a search by the military (or sections within it) for an expanded political base. In crude terms the new tolerance entails tactical concessions designed to cleanse the military's image and win over potential civilian allies. A major consideration would be the anticipation of possible forthcoming political struggles, most strategically for the presidency. At the same time, military elements selectively tolerate criticism of their competitors and opponents in the regime, allowing dissident proxies to weaken and undercut their legitimacy. This, to say the least, is a game which may be difficult or impossible to control.

\section{The Tradition of Dissent.}

Despite the authoritarian character of the New Order regime, a tradition of urban elite and middle class dissent has continued to exist in Indonesia. Today there exist a wide range of critical Non-Government Organizations (NGOs), human rights bodies, student groups, critical journalists, and quasi-opposition elite groupings like the Petition of Fifty and Forum Demokrasi.

In practical terms, the bulk of the public activity of most such regime critics today is essentially oriented to policy reform. These kinds of groups generate an endless stream of criticism of regime policy on matters such as human rights, development, and labor issues. They also focus on corruption and other barriers to rational and efficient administration. In effect, their work constitutes a continual battle for the reorientation of state policy over 
particular policies and for the rationalization of state administration. To some extent, this approach reflects a measured and explicit reforming, gradualist outlook on the part of many such regime critics. More importantly, it also results from the marginal and subordinated position of dissenting groups and their inability to organize openly and orient to the question of political power. ${ }^{21}$

The recent friction in the regime has opened up space for the pursuit of such activities, but it has also prompted debates about strategy for longer term regime change and democratization. There have been long-running debates about the appropriate orientation for civilian groups, given the clear depth of regime disunity and expectations of presidential succession. ${ }^{22}$ These debates have been wide ranging, although most accept and argue the need to take advantage of the current space to organize and strengthen the bargaining power of "civil society." Some, particularly younger and more radical activists, eschew any talk of conciliation with any elements in the regime. Beyond this is a basic division on whether the Suharto camp or the military are the key obstacle to democratic reform. On the one hand are those who emphasize Suharto's personal role in the development of the authoritarian system and consider that ultimately, given its military power, ABRI is certain to play a determinative role in any regime transition, and there is thus a need for civilian democratizers to orient to the military in some way (although there may be differences over just what such an orientation should consist of). On the other hand are those who view the military as the major institutional obstacle to democratization, and thus consider it more advantageous to make a tactical alliance with the Suharto and Habibie camp. This is the position especially of those Islamic intellectuals and activists who have joined ICMI, which NGO leaders like Dawam Rahardjo and Adi Sasono have argued can be viewed as an important means to promote the "civilianization" of government.

\section{Student Activism}

Student activists are a good entry point into some of these debates, not only because debates among student activists are rather more transparent than those in the elite opposition milieu, but also because of the place of students in New Order mythology. The 1966 student movement provided a display of apparent mass support for the overthrow of Sukarno, and thus gave the new regime crucial legitimation. This historic example of student-military "partnership" has been made much of in New Order discourse, and is lost on no one today.

The legacy of this collaboration was to color succeeding generations of student protest in the late 1960s and 1970s. Especially in the early 1970s student protesters were reluctant to condemn the regime in blanket terms. Rather, the emphasis was on regularization and reform on issues like corruption, development policy, and extra-constitutional institutions, especially Kopkamtib (the Command for the Restoration of Security and Order). At the same time, however, disillusionment increased with Suharto and what was seen as the circle of corrupt generals surrounding him. Elements in the movement preceding the Malari incident of January 1974 were motivated partially by the (misplaced) calculation that

\footnotetext{
21 Many regime critics, especially those in NGOs, have argued that their activity contributes to long-term processes of social and political change, which (at least for the present) avoids the question of regime change. Instead, many use terms such as "policy advocacy," "building a counter-hegemony," or "strengthening civil society" to describe their approach. This has enabled them generally to avoid repression and carve out a relatively secure, if marginal, position for themselves in the political system.

22 Indeed, many critics interviewed in 1993-1994 used the phrase Republik hamil tua (the Republic is in the advanced stage of pregnancy), with deliberate irony echoing descriptions used by the PKI in 1965.
} 
Kopkamtib commander Soemitro was preparing to seize power from Suharto, would be willing to do so if given the opportunity, or at least could be pushed in that direction in the same way that students forced the pace of change in 1966. Following this misreading of Soemitro's intentions, many student leaders were arrested and political activity on campuses was circumscribed.

The reemergence of student protest in 1977-1978 was marked by a hardening of attitudes toward the regime, reflected in the call for Suharto not to stand for re-election. In public, attitudes to the military remained conciliatory, with a common theme at many demonstrations a call for "ABRI to return to the people." At the same time, an undercurrent of anti-military sentiment had been evolving since the early 1970s. This emerged most clearly during the trials of student leaders which were held following the crackdown which took place in early 1978 . The defense speech of ITB student Indro Tjahjono, entitled Indonesia di bawah sepatu lars (Indonesia under the jackboot), was the most explicit student indictment of the military role in politics up to that time.

The crackdown following the 1977-1978 student movement was more comprehensive and effective than any preceding measures. Student councils were frozen and a permanent ban was placed on political activities on campus. Campus bureaucracies were given greatly extended rights to intervene in student activities. Collectively, these policies were known as NKK/BKK (Normalisasi Kehidupan Kampus / Badan Koordinasi Kemahasiswaan, Normalization of Campus Life / Body for the Coordination of Student Affairs).

The effect of NKK/BKK was further to marginalize student activism from the mainstream of Indonesian political life. During the 1980s it was virtually impossible for students critical of the government to organize openly on campus. Some became active in poor communities, working for those NGOs which were beginning to question some of the paradigms which had hitherto dominated developmental thinking. Others were involved in study groups which from the early 1980s began to mushroom around major campuses. Although such groups varied greatly in political outlook, most led a semi-underground existence, limiting their outside contacts to similar groups, a few critical intellectuals, and NGOs. In these kinds of groups students reevaluated previous generations of activism, searched for new strategies, and studied a broad range of critical theories, including dependency theory, the writings of the Frankfurt School, Latin American liberation theology, as well as classical Marxism.

The reemergence of a new and protracted wave of organized student protest was marked by an outbreak of protests against NKK/BKK and in favor of "campus autonomy" in Yogyakarta, Bandung, and Jakarta in the latter months of $1988 .{ }^{23}$ From early 1989 until the present, public demonstrations by student activists have been a commonplace, almost daily, occurrence in the main university towns of Java. A very broad range of issues, mostly with a human rights dimension, have been raised. The most common issues have included restrictions on the right to organize on campus, arrests or trials of student activists, irregularities in land disputes, and so on. Some campaigns have been particularly intense, such as those concerning major land disputes like that at the site of the Kedung Ombo reservoir in Central Java in 1989-1990, various trials of student activists in Yogyakarta,

${ }^{23}$ See for example, Tempo, November 12, 1988, p. 33; December 3, 1988, pp. 34-35; December 24, 1988, p. 80. 
Bandung, and Jakarta since 1989, or the banning of the news magazines Detik, Tempo, and Editor in mid-1994. ${ }^{24}$

The student protest movement which has emerged since the late 1980s has in several ways been quite different from those of the 1960s and 1970s. In the first place, its regional distribution has been distinctive. Both the 1966 generation and the 1973-1974 and 1977-1978 outbreaks were strongly Jakarta and Bandung centered. Although these cities have remained important, the new wave of activism has been much more widely and evenly dispersed, and in the years since 1989 sustained organizing has emerged in most of the important university towns of Java: Jakarta, Bandung, Bogor, Semarang, Yogyakarta, Solo, Salatiga, Surabaya, Malang, Jombang, and Jember. Student groups with links to those in Java also exist in Bali and Lombok, and have recently emerged in Medan and Menado. If anything, Central Java, and especially Yogyakarta, has been something of a focus, especially in the early period of 1989-1990 when Forum Komunikasi Mahasiswa Yogyakarta (FKMY, the Communication Forum of Yogyakarta Students) provided a model. ${ }^{25}$

Second, unlike in the 1960s and 1970s when students from the elite state universities (especially Universitas Indonesia, UI and Institut Teknologi Bandung, ITB) were the unchallenged pacesetters of the movement, new groups have involved many more students from smaller and less prestigious private campuses. In Jakarta in particular, at least until recently, UI has been conspicuously quiescent and students from private campuses there such as Universitas Nasional, Universitas Mustopo, Universitas 17 Agustus, and many others have played a more prominent role. In part this change reflects the fact that NKK/BKK was more rigorously applied to state universities, especially those which had been foci of political activism. But it also reflects the changing shape of tertiary education. Economic development has created demands for new skills and higher educational levels and has greatly expanded the market for tertiary education by producing a larger middle class with aspirations for upward mobility. As a result, the number of private tertiary institutions has mushroomed. According to figures released by the Ministry of Education and Culture, the number of private universities increased from 63 in 1978 to 221 in 1990, with much of the increase occurring in provincial centers (in Yogyakarta during the same period the number rose from five to eleven). ${ }^{26}$ Tertiary education is no longer the exclusive preserve of the upper reaches of the narrow, cosmopolitan elite of the big cities (many of whom, in any case, send their children overseas for study) as it arguably was in the 1960 s and even the 1970s. Instead, it has become more accessible to wider layers, including youths

\footnotetext{
${ }^{24}$ For a discussion of the issues raised in student protests in 1987-1990, see E. Aspinall, Student Dissent in Indonesia in the 1980s (Clayton, Vic.: Monash University Centre of Southeast Asian Studies Working Paper 79, 1993), pp. 17-21.

25 Although there are dangers in such generalizations, groups in the different towns and regions have tended to have distinct characteristics. Broadly speaking, Central Java and Yogyakarta have been the center of the new radicalism in the student movement. In Jakarta and Bandung, where students tend to have more elite backgrounds and where activists are more closely integrated with elite opposition circles, groups have tended to maintain more the traditions of the past. This has been especially the case at ITB where the legacy of the (some would say PSI-inclined) "Independent Group" of the 1970s has remained important. Activist groups in Jombang and Jember have been heavily influenced by the strong NU presence in these towns. But in more recent years, as inter-city networking has expanded, regional distinctions have tended to break down.

26 Daftar dan Status Perguruan Tinggi Swasta di Indonesia Tahun 1978 (Jakarta: Direktorat Jenderal Pendidikan Tinggi, 1979); Statistik Perguruan Tinggi Swasta Tahun 1990/1991 (Jakarta: Badan Penelitian dan Pengembangan Pendidikan dan Kebudayaan, Pusat Informatika, 1993).
} 
from lower middle class backgrounds (whether military, civil service, entrepreneurial, or professional) in the provincial centers. ${ }^{27}$

A third difference is organizational form. In the 1970s the student protest movement was largely organized by the legal and officially recognized elected student councils (Dewan Mahasiswa). This avenue was largely shut off by NKK/BKK. In the late 1980s and early 1990s the public face of student protest was largely represented by transient and ad hoc action committees, which would coalesce for a particular campaign and then disband. For example, Kelompok Solidaritas Korban Pembangunan Waduk Kedung Ombo (Group in solidarity with the sacrificial victims of the Kedung Ombo reservoir development) at its height in 1989 involved students from a number of cities, but was soon abandoned as the campaign declined. Such action committees would be alliances of less publicly visible groups based on particular campuses, which have remained the organizational bedrock of the movement. Often such campus-based groups are formed around the nucleus of a discussion group or a campus magazine or newspaper, and operate as organizing and recruiting centers. These first began to emerge in the mid to late 1980 s, when networking between cities also began. Open city-wide organizations which endeavored to coordinate formally the activities of the campus-based groups began to appear in the late 1980s. The prototype was the Communication Forum in Yogyakarta (FKMY) which in 1989 claimed a membership of 1,500 students from some twenty different campuses. ${ }^{28}$ Around the same time (1989-1990) similar organizations were established in other cities, the most prominent of which were BKMJ (Badan Koordinasi Mahasiswa Jakarta), Bakor (Badan Koordinasi Mahasiswa Bandung), and FKMS (Forum Komunikasi Mahasiswa Surabaya). Since then, although some of these groups, including FKMY, have declined and been replaced by new and sometimes competing city-wide organizations, there have been various attempts to organize more openly on an inter-city basis, with the formation, for example, of the loose coalition FAMI (Front Aksi Mahasiswa Indonesia, Indonesian Students Action Front), twenty-one of whose members were put on trial in early 1994, and SMID (Solidaritas Mahasiswa Indonesia untuk Demokrasi, Student Solidarity for Democracy in Indonesia) which is more tightly organized and was launched publicly at a congress in August 1994. ${ }^{29}$

The most striking difference between the student groups which emerged in the late 1980 s and the movement of the 1970s, however, was in political outlook. The more recent groups were dominated by a new and distinct radical-populist mood. Student activists "lived in" at villages targeted for development projects and organized political training and defense campaigns involving the affected communities, an altogether new phenomenon under the New Order. ${ }^{30}$ Their pamphlets, defense speeches, and essays stressed that they were interested in the basic empowerment of the poor, and often adopted a markedly more confrontational and radical tone than in the 1970s. Much of this literature stressed that, where the movement of the 1970s had taken up "elite" issues and attempted to intervene in national politics, the new movement was more concerned with struggling for the rights and interests of the common people-the rakyat. Indeed, the discourse of the movement was marked by a general tone of hostility to "elite politics," in large part based on the

\footnotetext{
27 Student activists, including many of the most radical, are from a broad range of middle class and elite backgrounds. Strikingly, but unsurprisingly, many are the children of middle and low ranking ABRI officers.

28 Tempo, April 24, 1989, p. 30.

29 Jakarta Post, August 4, 1994.

${ }^{30}$ For a discussion of some of the issues involved in such "land cases," see Anton Lucas, "Land Disputes in Indonesia: Some Current Perspectives," Indonesia 53 (April 1992): 79-92.
} 
understanding that the student movement of the 1970s had been ditunggangi (used, taken advantage of) by elite interests. Attitudes to the military in the new student movement were also generally more hostile than in the preceding generations. ${ }^{31}$

The new mood of populist radicalism in the student movement broadly reflected the marginalized position of student activism in the 1980s, whereby activists had ended up off campus, working with NGOs and searching for more thoroughgoing solutions for political and social problems. More particularly, it also resulted from the influence of the radical and structural theories which had been studied during the study group phase. Certainly a number of activists had been particularly influenced by this material and consciously strove to impart a more militant tone to the movement.

Although there was a core of more consistently radical activists, the New Order's depoliticization and "de-ideologization" of campuses (and society more broadly) also tended to obscure the contours of political debate in the new activist circles. Students critical of the government had been unable to participate in public political activity and had been little exposed to the open competition of differing political ideas. In contrast to the earlier period, under the New Order distinct ideological currents had been unable to emerge and compete on campuses. And indeed, the new activist groups would often contain members with widely varying family political backgrounds, with students with Sukarnoist, Islamic, or Christian heritages sometimes coexisting within the same group. ${ }^{32}$ All of this has contributed to the somewhat vague and essentially moral character of much of the populist student critique. Many student activists who have been active for many years say they are unable or unwilling to define their political outlook or aims, beyond a broad visi kerakyatan (populist vision) which entails a general defense of the poor and their political, economic, and social interests. Many activists argue that their actions are not motivated by ideological considerations or developed political aims, but that they are simply responding to visible injustices in Indonesian society. There is thus a strong strand in the student movement which continues the "moral force" - and hence essentially regularizing and reformist-traditions of the 1970s, albeit with a more populist tone. Indeed, some activists argue explicitly that the student movement is a moral rather than a political movement, and others view it in classic regularizing terms as a "social control."

Even from the earliest days of their emergence in the 1980s, then, there were incipient tensions in the new activist circles. Although many activists argued in essentially moral and regularizing terms, others identified strongly with more radical theories and were strongly influenced by radical student movements in South Korea and the Philippines.

Indeed, the movement has been marked by often bitter conflict, mutual recriminations, and suspicion. Often these do not have a basis in political differences, but stem from personal enmities, competition or tension between groups and regions, squabbles over funding, and so on. Some conflicts, however, have been caused by differences in political outlook. As the student movement has emerged from a virtually clandestine to a more open existence,

\footnotetext{
31 See Aspinall, Student Dissent in Indonesia in the 1980s, pp. 22-44 for a discussion of the themes of the new movement.

32 For example, students from the families of former Socialist Party (PSI) members or members of the Nahdatul Ulama Party or Islamic Students Association (HMI). The extent to which differing political currents have been blurred together in these groups is indicated by the fact that a number of groups (especially in Central Java) have attempted to reconcile Islam and Indonesia's radical heritage, by studying the experiences of the Sarekat Islam in the early 1920 s and reviving the writings of Haji Misbach and other early "red santri."
} 
there have developed two increasingly visible poles. In part, this process has been reflected in splits in the major student activist groups, especially in Central Java. ${ }^{33}$

On the one hand, there is a more consistently "populist" pole which maintains a vision of popular transformation, and continues to emphasize "mass" work-the organization of farmers, and (especially in the last two to three years) urban workers, and continues to eschew "elite politics." These students tend to be influenced by radical, structural analyses. This current more or less approximates, for example, the above-ground groups SMID and PRD (Persatuan Rakyat Demokratik, Democratic Peoples' Alliance). ${ }^{34}$

On the other hand, there is what is perhaps best defined as a "moral politics" pole which is closer to the mainstream tradition of student dissent in the early New Order. In addition to continuing campaigns on farmer and worker issues, over the last two or three years these students have increasingly raised what are sometimes referred to by student activists as "elite" issues concerning corruption and leadership in national politics. (This is highlighted by a series of protests directed against Suharto in 1993 which were strikingly similar to those of 1977-1978). These students tend to stress their moral motivations and the moral character of their struggle, the need for boldness and risk, and often see their role as being in large part as a pressure group able to raise sensitive issues to the political agenda. They tend to engage less than the populist groups in directly organizing farmers or workers; instead their typical modus operandi is often relatively small demonstrations which involve considerable risk. ${ }^{35}$ Many groups can be roughly identified with this current, including the prominent Jakarta organization Yayasan Pijar and the Students Action Front FAMI.

From the preceding discussion it is to be hoped that a rough picture has emerged of the kind of student groups with which this article is concerned. These are not the large and government recognized cross-campus organizations like HMI (Himpunan Mahasiswa Islam, the Islamic Students' Association) nor those groups which have mobilized around primarily religious issues. Rather, the focus is on those generally small groups, mostly in Java, which have been behind the spate of demonstrations in recent years on "human rights," "populist," and "democratic" issues.

\section{Student-Military Interaction: Clandestine Encouragement?}

The most elementary point to make about the relationship between the military and student activists during the openness period is that it remains dominated by repression. Over forty student activists have been tried on various political or criminal charges since

\footnotetext{
33 It must be stressed that this polarization is at an early stage, and the two poles are often difficult to distinguish in the activist milieu, consisting as it does of a huge number of small and transient groups, which often share a similar language and insist that they all share the same basic visi kerakyatan.

34 PRD aims at being an umbrella organization for various social sectors, but it draws heavily on students recruited in the 1980s and 1990s. On the launch of PRD, see reports in: Editor, May 5, 1994; Tempo, May 14, 1994; Kompas, May 4, 1994. The declaration issued by PRD on its formation calls for, inter alia, the "return to civilian supremacy," the "review of Dwifungsi and the security approach," removal of restrictions on the formation and operation of political parties, and the "return of the civil rights of ex-political prisoners."

${ }^{35}$ For example, many in Jakarta opposition circles criticized as "premature" a December 14, 1993, demonstration at the DPR building where some 200 students called for an extraordinary MPR session to hold Suharto accountable for a number of human rights violations. The response from one participant, when I put this to him, was "If students do not criticize Suharto, who will? If we do not do it now, when will we?" He was uninterested in longer term questions of political strategy and tactics, which he saw as an excuse for inaction on the part of "elite" critics, and said that students should be proud that they were once again in the vanguard, the first group to be bold enough to articulate openly the desires of a large segment of society.
} 
1988. Demonstrations are frequently broken up violently, and student activists—especially participants in land-dispute campaigns-have been tortured. Beyond this, activists are confronted by constant low-level monitoring, intimidation, and harassment. There is invariably a large security presence at demonstrations; intelligence officers frequently "drop in" at meeting places, and activists are frequently picked up "to chat" or for interrogation. Even at the campus level, there is often a state of virtually constant confrontation-often violentwith the campus Menwa (Student Regiment) which is under the direct supervision of the local military command.

Beyond this there are, of course, many other kinds of contact between student activists and officials, military and otherwise. For example, demonstrations frequently end in dialogue with government officials, who are often military officers. For present purposes, however, we are particularly interested in more informal, private approaches to student groups, and to what extent these have been viewed as "encouragement" by students. Certainly, since the reemergence of student protest in the late 1980s, many such approaches have been made.

One of the first examples occurred at an early stage of campaigning on land-dispute issues (early 1989), when a prominent military officer, initially disguised as a journalist, visited student activists in Central Java. This officer was considered by the activists I spoke to as "Benny's right-hand man." He asked many questions about the movement and the students' aims and concluded by telling them to contact him: "If you need anything, if you wish to criticize Suharto, if you need funds, if you need posters or anything like that." He also offered to put them in contact with the ABRI faction in the DPR. On leaving, he handed the students an envelope containing a large amount of money. This incident occurred at the beginning of the reemergence of the student protest movement, when the new emphasis on defending the poor and spurning involvement in elite conflict was very fresh. The students were somewhat perplexed by this approach, rejected the money, and did not follow up any of his offers.

A more regular pattern of contacts began in late 1989, involving some Jakarta student activists involved in campaigning regarding land disputes and similar issues. For some time, frequent informal contacts and dialogues took place between some students and local intelligence officers. Sometimes these were initiated by students, but more frequently by the military (often using threats and intimidation in the process). The officers would seek information about the students' activities and motivations, which would often lead on to more general discussions. For their part, students would use these opportunities to seek information concerning the "political constellation at the elite level," especially the "Benny split" and "the riches of Suharto and his family" -although on these particular occasions the military never openly criticized the president. However, they were more open concerning conflicts between ministers or scandals involving high-ranking regime officials (for example concerning Minister Sudomo's personal life). According to my informants, neither the military nor the students would openly discuss their own political views or plans: one activist suggested that each side was trying to make use of and manipulate the other.

In these discussions, the military officers would indicate sympathy with the students and their aims, approving their concern for the poor. A number of students suggested to me that these intelligence officers "encouraged" (mendorong) them to continue holding protests. At the same time, the officers would stress their concerns about stability and warn students against infiltration by the "extreme left." A number of informants also suggested to me that on a number of occasions money was offered to the students for their campaigning work, and on at least some of those occasions it was accepted. 
Intensive contact continued to take place between these activists and the military from late 1989 until 1992. It largely ceased following strong criticism of it by students from Central Java. Since 1992, the student movement in Jakarta has become more complex and splintered, but a number of activists continue to maintain informal contacts with the officers they got to know during the earlier period.

A number of informants in towns in East and Central Java told me that similar approaches from the military have occurred from time to time in those regions (although activists there tend to be more averse to such contacts than many of those in Jakarta), and were particularly intense through 1993 and early 1994. A frequent pattern was for military intelligence officers to call in at the boarding houses which serve as meeting places, and invite activists for dinner (or even sometimes to the movies). Again, in informal discussions on these occasions, the officers were mainly concerned with discussing the students' activities and criticisms, and would often profess sympathy for their motivations. More than this, officers would sometimes specifically indicate that they were disillusioned with President Suharto, with the corruption and business dealings of his family, and with their collusion with Chinese business interests. Sometimes they would go even further: in one case a BAIS (military intelligence) officer (in the recollection of one activist) told a student: "We share the same vision, we've both been disappointed and we should work together to overthrow Suharto."

It is impossible to gauge the full extent, implications, or meaning of these kinds of approaches. For example, it is striking that the most senior of the officers involved tended to be closely identified with Benny Moerdani. The more junior officers were, unsurprisingly, invariably from the intelligence services. In any case, it may seem tempting to conclude that what is involved is an attempt by military elements to manipulate and encourage student dissent and to position themselves for some kind of rerun of the 1966 "student-military coalition." In a general sense, it is clear that the officers involved have been attempting to forge close personal relations with a layer of activists, to win their sympathy, and build a level of trust. But this could serve any number of objectives, including simple intelligence gathering and, indisputably, the search for reliable agents. In a more long-term sense, however, the relationships and networks established by such informal contacts would constitute useful resources for possible future needs, including potential factional struggles.

When we turn to the larger question of the relationship between intra-regime tension and the emergence of protest, it is very difficult to sustain an argument that such contacts significantly "encouraged" student dissent and protest. It is not possible to assign military elements the role of dalang in this case. In the first place, such contacts were by no means uniform across all prominent activist groups, with many groups (especially the most radical, who are most often subject to violence) only rarely, if ever, approached. Furthermore, military officers invariably approached students after they had drawn attention to themselves by their activities, so the influence of such contacts can hardly be seen as a crucial factor in the emergence of protest. On the other hand, however, such contacts certainly did give students pause, and in a few cases, according to my informants, imparted a certain sense of confidence, a sense that they were being protected. Some (though seemingly a minority) became more sympathetic to the military as a result. More, however, told me that such approaches made them feel nervous and suspect that they were being manipulated by elite interests. At the very least, such contacts were consistently interpreted as further evidence of elite level conflict, which we will return to later in this article. 


\section{Demonstrations and Political Space.}

In the early 1980s, even relatively minor displays of defiance on campus were quickly repressed. ${ }^{36}$ Between late 1988 and mid-1994, despite many vacillations and often violent retreats, the regime, and more particularly the military, has adopted a relatively tolerant approach to student demonstrations. Although many demonstrations were still broken up violently, others were allowed to proceed more or less unhindered. Does this mean that discontented military elements have acted to "encourage" civilian dissent simply by adopting a soft approach to it?

Of course, at a general level it is impossible to separate intra-regime tension from all the other variables that have encouraged liberalization in this matter (which is, after all, at the very heart of the openness process). This kind of argument also tends to underplay the role dissenting groups themselves have played in pushing out the bounds of available political space during the keterbukaan period, often at considerable risk to themselves. Student activists have repeatedly confronted state repression over recent years, and in doing so have transformed public protest and demonstrations from a taboo to a day-to-day occurrence. However, there are a few particular cases where military leniency deserves comment, especially in demonstrations targeted against Suharto himself.

After the repression which followed student condemnation of President Suharto in early 1978 , the person of the president was largely considered a taboo topic by student activists. However, in early 1993, prior to and coinciding with the General Session of the MPR, a series of anti-Suharto demonstrations took place. The first occurred at a January PDI leadership council meeting at Kopo, Bogor, where students, going under the banner of Aliansi Demokrasi Rakyat (Peoples' Democracy Alliance) called for the PDI (Indonesian Democracy Party) to make good its promises from the 1992 general election and nominate an alternative presidential candidate. ${ }^{37}$ To my knowledge, this was the first demonstration since the late 1970s which was explicitly and exclusively directed against Suharto, and although the military used standard brutality against the protesters, it was a surprise to many that none of those taken into custody were formally charged.

This was followed by a demonstration outside the parliament building during the general session of the MPR on March 9,1993. A small number of student activists demonstrated their lack of faith in Suharto and called for him not to be reelected. Given the location and timing of the protest, this was an unprecedented open attack. And despite the presence of several hundred members of the security forces, it was allowed to go on for some time in full view of the national and international press. When security officers arrested five of the protesters, others were apparently ushered out of harm's way by military officers and told to get onto passing buses. Those arrested were held for just over twenty four hours.

Throughout 1993 student demonstrations on a range of issues-especially in Jakarta but also in other towns-became increasingly openly anti-Suharto, without inviting a military response. At a range of demonstrations, crude anti-Suharto slogans were shouted. On

\footnotetext{
36 For a description of the heavy-handed response to a number of student demonstrations which took place in Bandung between 1981 and 1986, see pp. 213-15. of the manuscript Indonesia: Kisah Tentang Sangkur dan Topi Baja-Merebut Kembali Hak Hak Rakyat, the defense speech of ITB student Ammarsyah in his 1990 trial.

37 See for example, Republika or Media Indonesia, January 12, 1993.
} 
November 10, for the first time since Malari, a student demonstration (against the state lottery, SDSB) was allowed to proceed to the presidential palace. ${ }^{38}$

According to a number of students who were detained on such occasions, the line of questioning during interrogation would often be directed at ascertaining whether they were anti-military or merely opposed to the president. On at least one occasion students' insistence that they were only anti-Suharto seemed to ensure their rapid release. In another case, a senior military officer, generally considered to be a Moerdani protégé, attended an interrogation, and was very open and friendly with the detained students, inviting them to keep in communication with him and providing them with his private phone number.

The 1993 protests against the state lottery also excited much speculation regarding military motives. During October and November a rash of very large demonstrations occurred in many towns in Java and other islands. Student participants to whom I spoke were universally surprised by the unusually soft-gloved approach of the military, to the extent that at some demonstrations students were given lifts aboard military trucks. It was commonly believed that this treatment was because members of the Suharto family were involved in the foundation running the lottery. These demonstrations were significant not only because of their scale and extent and the fact that they prompted a back down by the government, but also because they signify the increasing self-assuredness of Islamic groups in the changing political environment of recent years.

The demonstration at the DPR on December 14,1993, where twenty-one students were arrested (whose trials concluded in May 1994), is also of interest. For several hours the security personnel allowed some 100 students to protest in the DPR lobby. During this time the students attacked Suharto very forthrightly, holding up a banner reading Seret Presiden ke Sidang Istimewa MPR (Drag the President to an Extraordinary Session of the MPR) and openly shouting "Gantung Suharto" (Hang Suharto) and similar slogans. However, the main focus of the demonstration was.in fact the "security approach," including a call for the dissolution of Bakorstanas (Badan Koordinasi Stabilitas Nasional, National Stability Coordinating Board, wihch had replaced Kopkamtib in 1988). According to a number of informants, it was only when the students began to abuse the military that they were almost immediately attacked. This led many in student and elite opposition circles to conclude that the pro-

\footnotetext{
38 Most of the students and youths who were mobilized in the SDSB protests were not from the land dispute/ social justice-oriented groups which are the focus of this article. Groups like FKMIJ (The Jakarta Communication Forum of Islamic Students) and PMIB (The Bandung Alliance of Muslim Students), which played a large part in the organization of the 1993 wave of anti-SDSB demonstrations, were drawn mainly from hitherto largely cautious Islamic student ormas and less formal networks of mosque and pesantren-based youth and students. They had previously mobilized on a mass scale only on issues where the government was less directly implicated, such as international Islamic solidarity (especially Palestine and Bosnia) and other moral or religious issues (such as the Monitor case in 1990). However, many of the activists from the groups considered in this article were also involved. They were instrumental in many demonstrations during the first wave of anti-SDSB protest in late 1991 and also participated during the second wave in 1993. Indeed, during the course of the campaign in 1993 there were frequent tensions between the Islamic activists and activists from the "social justice" groups, who considered the campaign to be expressed too much in religious terms and not sufficiently anti-government. This was vividly expressed in the November 10 demonstration which split in two, with only a minority of the most militant activists proceeding to the palace.
} 
testers were injudicious for attacking two competing powers at the same time. ${ }^{39}$ Following the first session of the trial of the twenty-one, a student activist remarked: "IIn the courtroom] we shouted 'hang Suharto' and all of the military people there didn't touch us. If we'd insulted the military-we would have been wiped out (disikat)."

It may be tempting to speculate about these kinds of cases, in a "politics as wayang" vein, but it is difficult to draw clear conclusions from them about the character of tensions in the military and regime. Their significance for present purposes lies more in the fact that these and similar cases, as well as the kinds of informal contacts discussed earlier, have been widely interpreted by student activists as evidence of the existence of such tensions.

\section{Student Attitudes to the Military}

The way in which student activists interpret private approaches by military officers, and how they perceive conflict within the regime and attempt to take advantage of it, varies greatly between different individuals and groups. Attitudes on such matters are influenced by many factors-including the extent of personal contacts with military officers, and relations with particular groupings, networks, or individuals in elite dissident circles. But the debates which have taken place in this context do convey something of the kind of political outlooks prevalent in one section of the middle-class "opposition."

It is worth stressing at the outset that underlying their differences regarding strategic and tactical matters, a broad consensus exists amongst most activists from the kind of groups with which this article is concerned. They agree that one of their ultimate aims is the withdrawal of the military from political life. Unlike the situation in the 1970s, when the 1966 coalition was a comparatively recent memory, the immediate historical backdrop of the present student movement is the much more hostile relationship between the military and students in the 1970s and early 1980s. Contemporary activists tend to believe that the students in 1966 helped disguise the military's rise to power, and they stress their determination not to repeat these earlier actions. ${ }^{40}$

\footnotetext{
39 See the interview with one of the twenty-one students, Yeni Damayanti, in Editor, April 28, 1994. It is noteworthy that press coverage of the arrests and trials (and, indeed, the trials themselves) has concentrated on the attacks the students made on Suharto, all but ignoring their criticisms of the military. For an interesting discussion of this case and its implications concerning tensions in the regime, see Yosep Adi Prasetyo, "Penyidangan 21 Aktivis Mahasiswa: Pergelaran Teater Kebangsaan," in Bina Darma 12, 45 (1994): 101-19.

40 It should be noted, however, that those students who have so far engaged in protest and entered the strategic debates discussed below have been in the vanguard of middle class political activism-the risks which they have taken testifies to the fact that they are among those most vehemently opposed to the present regime. It is not surprising, then, that anti-military sentiment is strong among them. If the process of liberalization continues to unfold, it can be assumed that increasingly moderate political groupings, more willing to contemplate cooperation with regime or military elements, will move into action. In the case of students, this applies especially to the cross-campus ormas, which up to the present have been extremely cautious about risking their large numbers, and instead argue privately that they are waiting for the appropriate "momentum." Indeed, there are indications that this process is beginning. It appears that increasing numbers of HMI students have recently been organizing and participating in demonstrations (although not under the name of HMI) - especially on SDSB and the Bapindo scandal. Or see, for example, an almost euphoric meeting in January 1994 between representatives of student senates-which tend to be dominated by ormas and have until recently been largely politically quiescent-and former Kodam Jaya commander Hendro Priyono to discuss, amongst other things, the December 14, 1993 case. At the end of this meeting, Hendro (after he had promised extra visiting rights to the detained students and given sports shoes to many of those in attendance) was raised up onto the students' shoulders as they shouted his praises: See Detik, February 2-8, 1994.
} 
At one end of the spectrum of views amongst activist groups, there is absolute opposition to even contemplating collaboration with elements from within the military, and similar opposition to concentrating criticism on any one particular "elite faction," such as the Suharto camp. This is a common view especially among more "populist" groups-those activists who tend to work more consistently among workers and farmers and are hostile to "elite" issues (and are often located further from Jakarta, in Central and East Java). Those students who are more self-consciously radical like to describe the Indonesian political system as militarist or fascist. In the words of one, "the enemy of the people is not 'Suharto versus pro-democratic or anti-Suharto elements', but rather 'militarism versus the Indonesian people."' In the clandestine material of the more radical groups, opposition to the military and to dwifungsi occupies a central position, although they are limited in the extent to which they can express this publicly. A conscious tactic at the campus level is to campaign against the Menwa (student regiment), as a means to encourage anti-militarist sentiment among students.

There are also strong moral overtones in much of the opposition to "softness" toward the military. For many activists a simple moral principle is involved: military officers are part of the elite which represses the rakyat; they have been responsible for much bloody repression; and hence any idea of collaboration with them must be opposed. To do otherwise would be to undermine students' moral integrity as a "pure" (murni) force, outside and independent of a tainted power structure. And so many groups which cannot be described as left-wing also tend to reject contact with the military, and refuse offers of military funds. If they do accept a military invitation to dinner or an informal dialogue (and sometimes these invitations engender debate in groups about whether or not they should be accepted), they use it as an opportunity to underline their opposition to the military's political role. ${ }^{41}$

This kind of morally motivated opposition to conciliation with the military is part of the broadly populist outlook in the student movement, one element of which is extreme hostility to all forms of "elite politics." For example, a number of Surabaya students told me that they would not pursue any "elite" issue (the example being discussed was Sudomo's involvement in the Bapindo banking scandal), because there was a possibility that their actions could be used by an opposing elite faction for its own advantage. Another group told me that they should not take up issues which are "too high level" (in contrast to local campus, farmer, or worker issues) because to do so is to risk being "eaten up by the elite." This hostility to the elite and their politics extends to leading dissenters. For example, students who publicly nominated noted critic Ali Sadikin and retired general Mohammed Yusuf for president before the 1993 MPR session, were criticized in some circles for merely furthering the interests of one element of the elite.

These kinds of student activists, who deliberately strive to avoid elite politics, thus do not employ any specific stratagem to make use of the opportunities afforded by intraregime disunity. Rather, they simply continue to engage in political activity, deepen their organizing work, make increasingly bold and confrontational actions and demands, and, by doing so, strive to widen the space available for political action.

However, there are also a range of more conciliatory attitudes regarding the military among other student activists. In large part these attitudes reflect broad agreement among

\footnotetext{
41 One example was a February 25, 1994 open dialogue with student activists and student senate representatives which was requested by the Commander of the East Java Territorial Command, Major General Haris Sudarno. Activists from FKMS used this opportunity to demonstrate their opposition to the "security approach" and to call for the dissolution of Bakorstanas: See Surya, February 25, 1994.
} 
many in elite opposition circles-such as academics, NGO leaders, or retired generals-that it is a tactical error to target Suharto and the military simultaneously. And so, as a section of the student movement has moved away from the extreme margins of political life and become closer to these circles, there has been something of a shift in the targets of their criticism. In contrast to the late 1980s, when the focus was on land disputes and other local issues, in recent years, as described above, demonstrations directly targeted against Suharto have occurred. There is also an increasing focus on Suharto in student magazines and the anonymous leaflets and brochures which circulate among students. ${ }^{42}$

Behind the reemerging emphasis on Suharto are a range of considerations. Many students, of course, are not motivated by tactical or theoretical considerations, but by simple moral reprehension-Suharto as president and embodiment of the New Order is a logical and obvious target for anti-regime vitriol. For other students, it is a simple question of not multiplying the movement's opponents unnecessarily, of avoiding repression. They consider the risks entailed in a frontal assault on the military as too high and have noted that military elements appear to allow a certain-but by no means absolute-space for criticism of Suharto.

Other activists, however, are influenced by broader strategic considerations. For example, it is sometimes argued that Suharto (rather than the military, as some ICMI intellectuals see it) is the main obstacle to democratization, who must be confronted first, and that it is impossible to envisage significant reform without Suharto's removal. They consider that focusing on Suharto would enable a broad opposition front to be built, and that only after his removal would it be possible realistically to make demands for changes in the political system or the structure of society. In the words of one activist: "How many times have we criticized the DPR for being unrepresentative and ineffective, as being a bunch of clowns [badut]? But it's been impossible to make any changes to it-because in the end it always comes back to Suharto." The same person described the focus on Suharto as an "entry point" for a struggle for structural change.

Indeed, in a movement which since the 1980 s has been thoroughly imbued with the language of "structural change," Suharto himself is sometimes described as a structural obstacle by these students. One activist explained that it is false to counterpose Suharto to the "system," arguing that the system has become personalized, that the two are identical. To remove Suharto is necessarily to change the system. Often this kind of approach is justified by describing the New Order as modern version of a traditional Javanese sultanate. Amongst many activists there is a-often half-joking - tendency to describe all social and political problems and injustices as being "because of Suharto." There is even an acronym to describe this concept: UUS-Ujung-ujung Suharto, which, roughly translated, means "something which can be traced back to Suharto."

And so there is one body of student activist opinion which argues that criticism of any political problem should be directed back to Suharto: all criticism should be "di-UUS-kan." This approach was most succinctly expressed by the sticker distributed at a November 1993 anti SDSB demonstration: Soeharto: Dalang Segala Bencana: SDSB, Nipah, Haur Koneng, Dili, Tanjung Priok. 43 (Nuku Suleiman, chairperson of Yayasan Pijar, was sentenced to five years'

\footnotetext{
42 For example, the first 1993 edition of the Yogyakarta Sunan Kalijaga IAIN student magazine Arena, which detailed the business interests of the Suharto family and was subsequently banned.

43 "Soeharto: Dalang of all disasters: ..." Nipah and Haur Koneng refer to incidents where civilians were killed in Madura and West Java in 1993, Dili refers to the 1991 Santa Cruz massacre, and Tanjung Priok refers to a massacre in Jakarta's port district in 1984.
} 
imprisonment for distributing the sticker.) In the same way, anti-Suharto slogans are shouted at a wide range of demonstrations, a protest against the "security approach" is used to call for the president's impeachment, and demonstrations concerning the Bapindo banking scandal are used to highlight Suharto's alleged personal involvement. ${ }^{44}$

This kind of approach has sparked a real debate amongst student activists, especially given the dominant populist flavor and emphasis on "structural" change in the movement since the 1980s. At a number of meetings I attended there was lively discussion of this topic, with some saying anti-Suharto students were playing into the hands of the military, that they were risking a repeat of 1966, and that they were, in effect, aiming only at a change in "person" rather than "structure." 45 Comparisons were made with the replacement of Marcos in the Philippines, which radical students consider resulted in no meaningful structural change. The notion that Suharto himself constitutes a structural obstacle to democratization has been developed in response to such criticisms.

Another response has been that student activists and other regime critics can avoid being used by the military in this process by making use of the space afforded them by attacking Suharto in order to strengthen the organizational and mass base of their movement, and to strengthen civil society more broadly. This is a common argument in broader dissident circles: that the only way to avoid military cooptation in the attack on Suharto is to build a strong base so that civilian forces may have greater bargaining power in a future process of regime change. This view is often implicitly (or explicitly) based on a gradualist and negotiation-centered conception of democratic transition.

In many respects a tactical alliance with discontented military elements would seem to be the logical next step for those students who advocate the anti-Suharto approach. (Indeed it could be argued that students who focus on Suharto are already in de-facto alliance.) Of course, the great many uncertainties which currently obscure the real dimensions of military discontent and intra-regime conflict, mean that any kind of open coalition is for the present out of the question. Nevertheless, there is an unfinished and ongoing debate on this matter, with many activists unsure of what position to take. At the present, however, most activists I interviewed-even those who argue in favor of focusing on Suharto-have strong feelings against collaboration with military elements. At a number of meetings I attended, where student activists discussed the question of strategic alliances, there was universal agreement that students should cooperate with workers and farmers. On whether the military, or elements within it were a potential ally, most views were extremely negative, with only a few students being even somewhat equivocal. Anti-militarist sentiment remains dominant in those activist groups which have organized many of the protests of recent years.

\section{Conclusion}

The relationship between intra-regime friction and civilian dissent, in this case student protest, is obviously complex. Clearly it is not a simple case of "encouragement" of student

\footnotetext{
44 See, for example, a poster carried by a demonstrator at a Bapindo demonstration, which is visible in a photograph on p. 23 of Editor, March 3, 1994: "Kasus Nuku, Kasus Ria Irawan, Kasus Bapindo, Semuanya UUS" (The Nuku, Ria Irawan, and Bapindo cases are all UUS). Nuku Suleiman was on trial at this time. Ria Irawan is a movie star linked to a scandal surrounding the death of a young businessman in Jakarta in early 1994. This scandal was the subject of much rumor in opposition circles concerning the possible involvement of a member of the presidential family.

45 Similar criticisms are made concerning FAMI's emphasis on Suharto in an article entitled "An Evaluation to Incident of December 14 1993" in Indonesian Mobilization (September 1993-January 1994, no 2), an English language newsheet produced by some of the more radical activists.
} 
activists by military elements. The dalang model of Indonesian politics might seem attractive in the framework of a patrimonial or cultural politics analysis, where politics are conceived in terms of conflict between factional appanage wielders, using vast patron-client pyramids extending out into civil society. However, at least in the upsurge of student protest which has taken place since the late 1980s, direct contact with military elements has been a minor factor. Although some groups might have been encouraged by their clandestine or informal contacts with the military, most activists-especially outside Jakarta where protest has been most intense-actually opposed such contacts in principle.

The relationship has been in the main more indirect. On one level, it is difficult to argue against (and certainly difficult to disprove) a "taking the lid off" explanation-that dissatisfied military elements have encouraged dissent by taking a softer approach to it. In particular cases, a surprisingly relaxed attitude has been apparent and there has been an overall softening over the entire period. But in many cases-especially those where students mobilize alongside farmers or workers-repression has been just as brutal as in the old days. The relationship is obviously more complex, with dissenting groups attempting to read the character of regime friction and to take advantage of it by testing the boundaries of military toleration of dissent (a process which has involved significant risk and considerable bravery).

It is thus important not to downplay the independent role played by dissenting civilian groups in this process. It may be a semantic point, but groups in civil society require little "encouragement" to protest and dissent. There is clearly widespread dissatisfaction among educated middle class youth and in the lower classes (which to some extent has been articulated by students). Student activist groups, although they may be relatively inexperienced, are independent political actors, who are-as the discussion above indicates-engaged in very real debates, making difficult choices on tactical and strategic matters. They are not merely the passive tools of elite factions, and, like other groups in civil society, they have played a significant role in pushing forward the liberalization process over the last seven or so years, not least by re-institutionalizing public protest as a normal feature of political life and by raising a number of issues to the public agenda-particularly land disputes, human rights violations, and labor issues. In the process, they have challenged and often overstepped the limits of toleration by the repressive apparatus of the state.

This is not to deny that, up to the present and on the whole, the state, including its military component, has been the ultimate arbiter of the liberalization process. Ruling elements may have been pushed some way further in the keterbukaan process than they wished, but not to the extent that their interests have been significantly threatened. Similarly, frictions in the regime have not deepened into the kind of fissures which would provide a decisive opening for oppositional groupings in civil society. In coming years, a key will be the extent to which civilian forces are able to make use of the space provided by this process to organize politically in an effective manner. To the present, dissenting groups have largely been unable to do this. There have been a wide variety of initiatives, and certainly in the NGO field regime critics have a strong institutional base, although not one ideally suited for political campaigning. Initiatives taken by elite opposition and critical elements to broaden and organize a support base, particularly FPKR (Forum Pemurnian Kedaulatan Rakyat: the Forum for the Purification of Peoples' Sovereignty) and Forum Demokrasi have largely stagnated. The student movement remains disunited and on the whole poorly organized. One recent and potentially important initiative at the populist end of the opposition spectrum was the formation of the Democratic People's Allaince (PRD), but this organization is still small. 
An important development indicated by the debates among students discussed above is the emergence of a new mood amongst sections of educated youth activists. Sentiments of acute hostility to the military, and to the elite as a whole, as well as the posing of mass organizing as an explicit alternative to collaboration with elite groups, all reflect populist and sometimes even revolutionary urges in a part of the student movement. An embryonic left is clearly reemerging in Indonesian politics, although it remains small. More broadly, the anti-militarism and radicalism of student politics also reflects a process of deepening alienation from the regime-not only on the part of student activists but also in broader layers of society. A range of social problems which have been engendered and exacerbated by the growth and spread of capitalism under the New Order-contradictions between city and country, developers and farmers, workers and capital-underlie this alienation.

On the other hand, there are plenty of counter-indications. Counterposed to the more populist mood of one wing of the student movement are more gradualist and reforming outlooks, in the tradition of the "moral force" and regularizing movements of the 1970s. These students see themselves in terms of pressure-group politics or as a social control. Despite an overlay of harsh anti-regime and anti-military sentiment, there is a clear logical dynamic amongst some students in the direction of a potential coalition with military elements. Certainly, the military remains the most powerful institution in Indonesia, with the greatest capacity to control the transition to the post-Suharto era. However, moves toward an alliance between a section of student activists and elements from the military are complicated by not only the inconclusive and uncertain character of intra-regime friction, but also by a strong anti-militarism which did not exist amongst potential allies of the military in 1965-1966. 